\section{Chemical Changes during Storage of 'Barhi' Dates under Controlled Atmosphere Conditions}

\author{
K.N. Al-Redhaiman ${ }^{1}$ \\ Department of Plant Production and Protection, College of Agriculture and \\ Veterinary Medicine, King Saud University, Al-Qassim, P.O. Box 1482 Buraidah, \\ Kingdom of Saudi Arabia \\ Additional index words. Phoenix dactylifera L., date fruits, postharvest, modified \\ atmosphere, storage, chemical composition
}

\begin{abstract}
Mature 'Barhi' dates (Phoenix dactylifera L.) were stored in air or under controlled atmosphere (CA) storage conditions with $5 \%, 10 \%$, or $20 \%$ carbon dioxide concentrations (balance air) during storage at $0^{\circ} \mathrm{C}$. CA conditions extended date storability by maintaining fruit quality. Fruit quality was maintained for 26 weeks when stored in $20 \% \mathrm{CO}, 17$ weeks in both $5 \%$ and $10 \% \mathrm{CO}_{2}$, and 7 weeks in air. Treatment with $20 \% \mathrm{CO}_{2}$ maintained fruit color, firmness, $\mathrm{SSC} \%$, total sugar content, and total tannins. $\mathrm{CO}$ treatment also reduced degradation of caffeoylshikimic acid (CSA), which is one of the major phenolic compound of date fruit. This study indicates that 'Barhi' dates could be stored under CA conditions in cold storage with good eating quality for 17 to 26 weeks.
\end{abstract}

Date palm (Phoenix dactylifera $\mathrm{L}$.), the tree of life, is the major fruit tree in most Arabian countries and it is widely grown in the middle eastern countries. Some date fruit cultivars are consumed at full mature stage while others are consumed at ripening stage. 'Barhi', the most popular cultivar worldwide, is marketed and consumed at the full mature stage of development. However, its economical value decreases sharply when it ripens as surplus production has to be sold at lower prices. A strategy for producers could be to export dates to foreign markets, butrequires application of modern technology to handle and store fruit at the full mature stage to delay fruit ripening. Few trials have been carried out to maintain fruit quality during storage of dates, including low temperature (Hassan and El-Sheemy, 1989; Hegazy et al., 2003), coating with polypropylene films (Thompson and $\mathrm{Ab}$ boodi, 2003), or using polyethylene bags (Attia et al., 1997). However, responses of fruit quality to these treatments have been limited.

Fully mature soft dates initially have a high moisture content (Coggins and Knapp, $1969)$ that is comparatively much higher than the critical value of $23 \%$ for yeast fermentation and fungal attack (Rygg et al.,1953). In addition, dates at full mature stage are rich in antioxidants, especially phenol compounds (Modafar et al., 2000; Ramos et al., 1997). Tannin contents, which are the most dominant phenol compounds in date fruit, decline as the fruit ripen (Rouhani And Bassiri, 1976; Sawaya and Mashadi,1983).

The use of elevated $\mathrm{CO}_{2}$ in the storage atmosphere for maintaining fruit quality has

Received for publication 1 Feb. 2005. Accepted for publication 8 Mar. 2005. The author is thankful to Chris Watkins, Postharvest Science, Department of Horticulture, Cornell University, Ithaca, N.Y., for his help and guidance in writing and revising this manuscript.

'E-mail khalid1963@hotmail.com. been described(Al-Redhaiman, 2002; El-Rayes and Ahmed, 2001; Kader, 1980). Optimal MA combinations have been developed for different species, and even cultivars within the same species (Kader, 1997). Although the effect of modified atmosphere (MA) treatments on quality preservation and control of nitidulid beetles of dried date fruit has been studied (Navarro et al., 1998), no information about responses of soft fully mature dates is available.

Our objective was to determine the possible use of carbon dioxide as a postharvest treatment to extend the storage period while maintaining the quality or the chemical composition of full mature 'Barhi' dates.

\section{Materials and Methods}

Plant material. Seven mature 'Barhi' date palms grown at the experimental research station, College of Agriculture, King Saud University, Buraidah, Al-Qassim, the Kingdom of Saudi Arabia, were selected for the study. All palms were almost of the same age and uniform in growth. The palms were in good physical condition, free from insect damage and diseases and were subjected to the same management treatments.

Fruit were harvested at full mature stage, according to skin color (the whole fruit should be yellow, and the yellowish green area should not exceed $10 \%$ ) and soluble solids content (SSC) $>28 \%$ (Hegazy et al., 2003). Immediately after harvest, fruit were transported to the postharvest laboratory where those of similar shape, color, and degree of development were divided into groups and were wiped free of dirt and kept immediately at $0{ }^{\circ} \mathrm{C}$.

Treatments. Five replications of each treatment were stored in well sealed gas tight glass containers equipped with inlet and outlet valves, and $\mathrm{CO}_{2}$ was injected from gas cylinders to provide concentrations of $5 \%, 10 \%$, or $20 \% \mathrm{CO}_{2}$ in air. Supply and exhaust $\mathrm{CO}_{2}$ gas composition was monitored using a gas chromatograph(Carle analytical series S). Air storage was used as a control for all of the experiments. All containers were stored at $0{ }^{\circ} \mathrm{C}$.

\section{Analyses}

Monthly samples (10 fruit per replication) were removed and frozen immediately for determinations of total tannin, sugars (reducing and nonreducing), and caffeoyl shikimic acid(CSA) contents. Each treatment was terminated when the number of ripe fruits in each spike exceeded the number of the unripe fruit.

SSC was measured with a temperature-compensated refractometer (RFM 110; Bellingham + Stanley LTD, Lawrenceville, Ga.). Reducing and non-reducing sugars were determined colorimetrically according to Dubois et al. (1956) using a spectrophotometer (Ez301; Perkin Elmer, Shelton, Conn.). Total tannin content was determined according to the Association of Official Agricultural Chemists (1975).

CSA extraction was carried out using Soxhlet extractor (Electrothermal-Ectromantle ME, England) at $40^{\circ} \mathrm{C}$ for $6 \mathrm{~h}$ using $10 \mathrm{~g}$ of sample powder (samples were ground three times for $15 \mathrm{~s}$ in an analytical mill (Grindomix GM200; Retsch, Haan, Germany), and $200 \mathrm{~mL}$ of ethyl acetate solvent. The crude solvent extracts were filtrated through Whatman No. 1 filter paper and then dried using a vacuum rotary evaporator (Buchi 011; Buchi, Switzerland) below $40{ }^{\circ} \mathrm{C}$. CSA was measured by using HPLC system consisting of a Consta METRIC 4100 series pump, spectra series AS-100 auto sampler, spectra system FL 3000 fluorescence detector. Column used was a reversed-phase water Spherosorb ODC-2 (3 $\mu \mathrm{M} ; 150 \mathrm{~mm} \times 4.6$ mmi.d.,Alltech). The HPLC conditions were as follows: injection volume $=20 \mu \mathrm{L}$, detector $=$ Fluorescence Ex 250 to $400 \mathrm{~nm}$, mobile phase $=12$ methanol : 88 ammonium acetate $(\mathrm{v} / \mathrm{v}$ at $\mathrm{pH}$ 5.4), and flow rate $=1 \mathrm{~mL} \cdot \mathrm{min}^{-1}$.

Statistical analysis. Data were analyzed using a complete randomized block design with five replicates per treatment, using the Student-Newman-Keul's test. The least significant differences were used to compare means at $P$ $\leq 0.05$ according to the procedure outlined by Snedecor and Cochran (1980). The experiment was carried out for two successive seasons.

\section{Results and Discussion}

Storage period. Elevated $\mathrm{CO}_{2}$ extended the storage period of fully mature 'Barhi' date fruit (Table 1) by retarding ripening and senescence.

Table 1. Storage period of 'Barhi' date fruit stored at $0^{\circ} \mathrm{C}$ under different carbon dioxide concentrations.

\begin{tabular}{lc}
\hline $\begin{array}{l}\mathrm{CO}_{2} \text { concn } \\
(\%)\end{array}$ & $\begin{array}{c}\text { Storage period } \\
\text { (weeks) }\end{array}$ \\
\hline 0.03 & $7 \mathrm{a}$ \\
5 & $17 \mathrm{~b}$ \\
10 & $17 \mathrm{~b}$ \\
20 & $26 \mathrm{c}$ \\
\hline
\end{tabular}

Means in the same column with different letters are significantly different $(P \leq 0.05)$. Each value in the table is the mean of five replications, and three measurements were conducted for each replication. 
Control fruit started to lose their eating quality after 7 weeks of storage and were discarded after two months. $\mathrm{ACO}_{2}$ concentration of $20 \%$ extended the stored period of fruit 3.71 times that of control fruit. The effect of $\mathrm{CO}_{2}$ was proportional to its concentration.

Sugar content. The total sugar content in the fruit at the beginning of the experiment was $75.3 \%$ (dry weight basis) and increased at different rates during storage depending on the treatment (Fig. 1A). The highest rate of change occurred in control fruit while the lowest increase occurred in fruit stored in $20 \% \mathrm{CO}_{2}$.
Nonreducing sugar contents were relatively low at the beginning of the storage period, (6.5\% on a dry weight basis). Contents decreased slightly in fruit from all treatments during the first month of storage (Fig. 1C). However, as the storage period proceeded, they dropped very rapidly in air-stored fruit to undetectable levels. $\mathrm{CO}_{2}$ in the storage atmosphere reduced this loss, the greatest effect being observed at $20 \% \mathrm{CO}_{2}$.

In contrast reducing sugar contents increased rapidly in air stored fruit and this increase was inhibited by elevated $\mathrm{CO}_{2}$ (Fig. 1B).

A decrease in the sucrose content at the later stage of maturity and the increase in the reducing sugars values are synchronized with the rising activity of the invertase enzyme which is a characteristic of all date cultivars (Sawaya and Mashadi, 1983). The action of $\mathrm{CO}_{2}$ on these processes may be associated with lower rates of respiratory metabolism.

Total tannin contents. The more advanced stage of ripening, the lower the fruit tannin contents decreased as fruit ripening advanced and these changes were delayed by elevated $\mathrm{CO}_{2}$ (Fig. 2A).

Soluble solid content. SSC was not affected

(A)

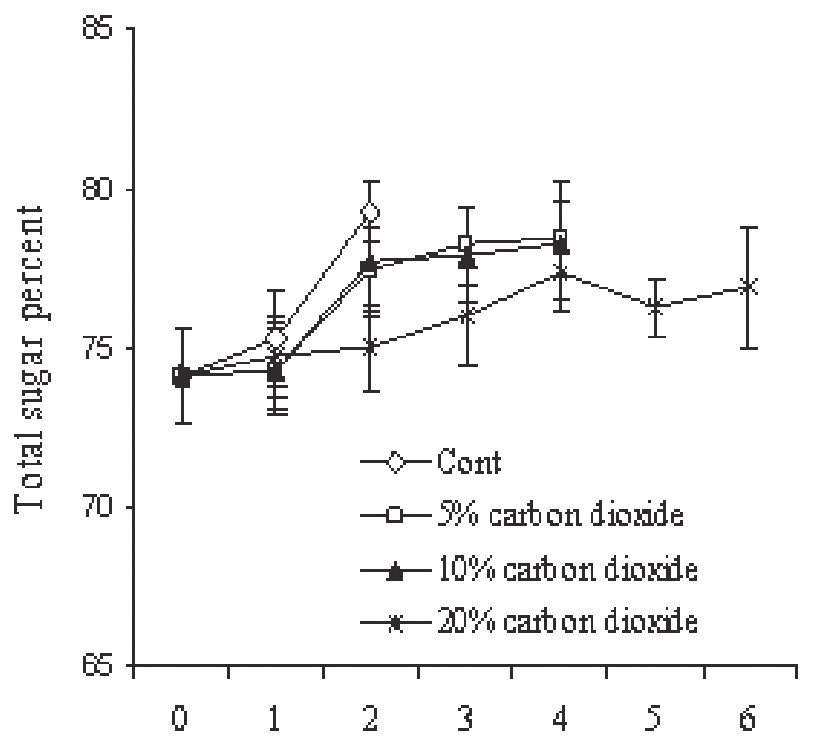

Storage period (month)

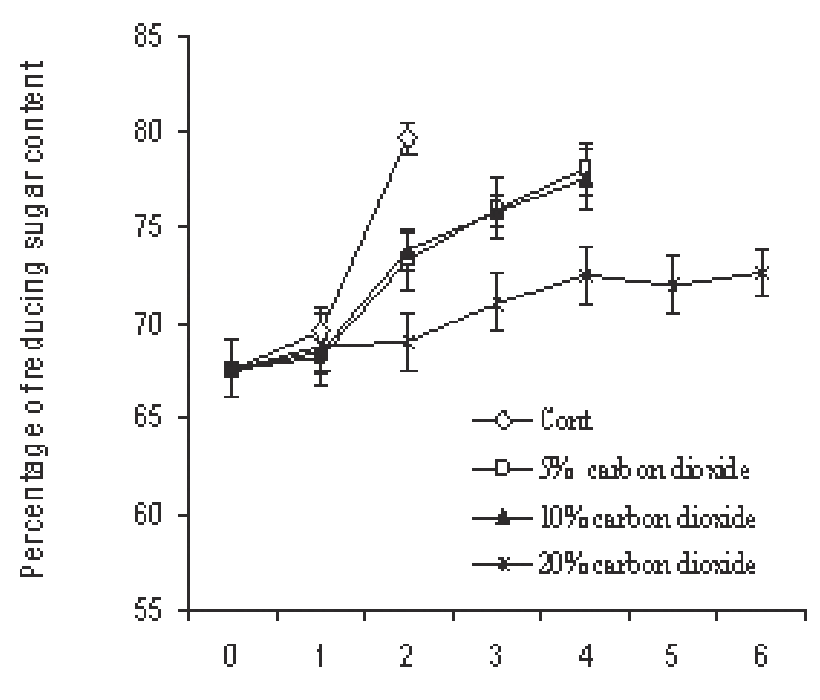

Storage period (inonth)

( C )

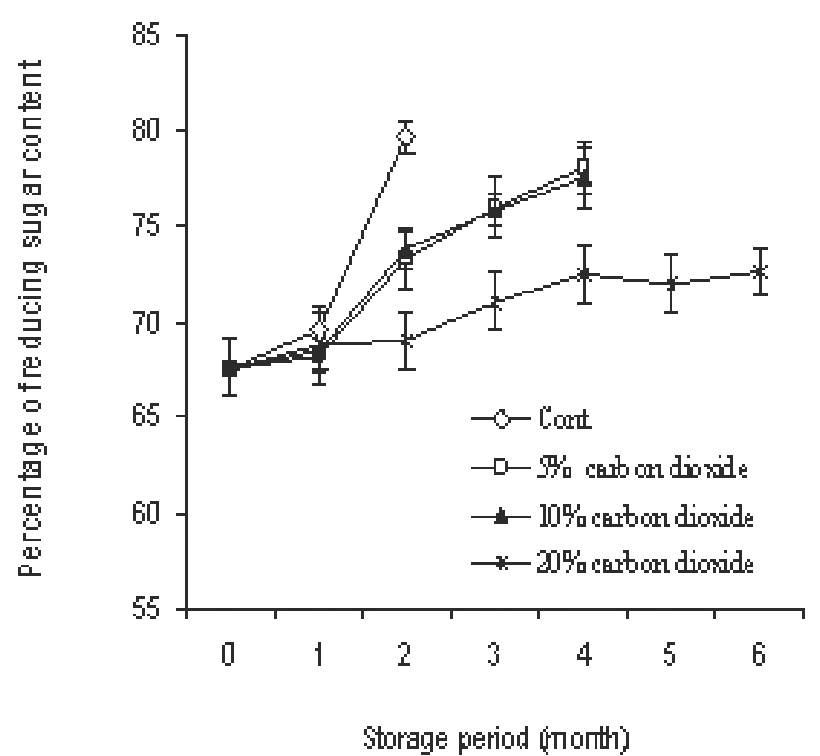

Fig. 1. Effect of different $\mathrm{CO}_{2}$ treatments on (A) total sugars (\%), (B) reducing sugars (\%), and $(\mathbf{C})$ nonreducing sugars $(\%)$ of 'Barhi' dates stored at $0{ }^{\circ} \mathrm{C}$. Verticle bars show SE values of five replications. Three measurements were conducted for each replication. 
(A)
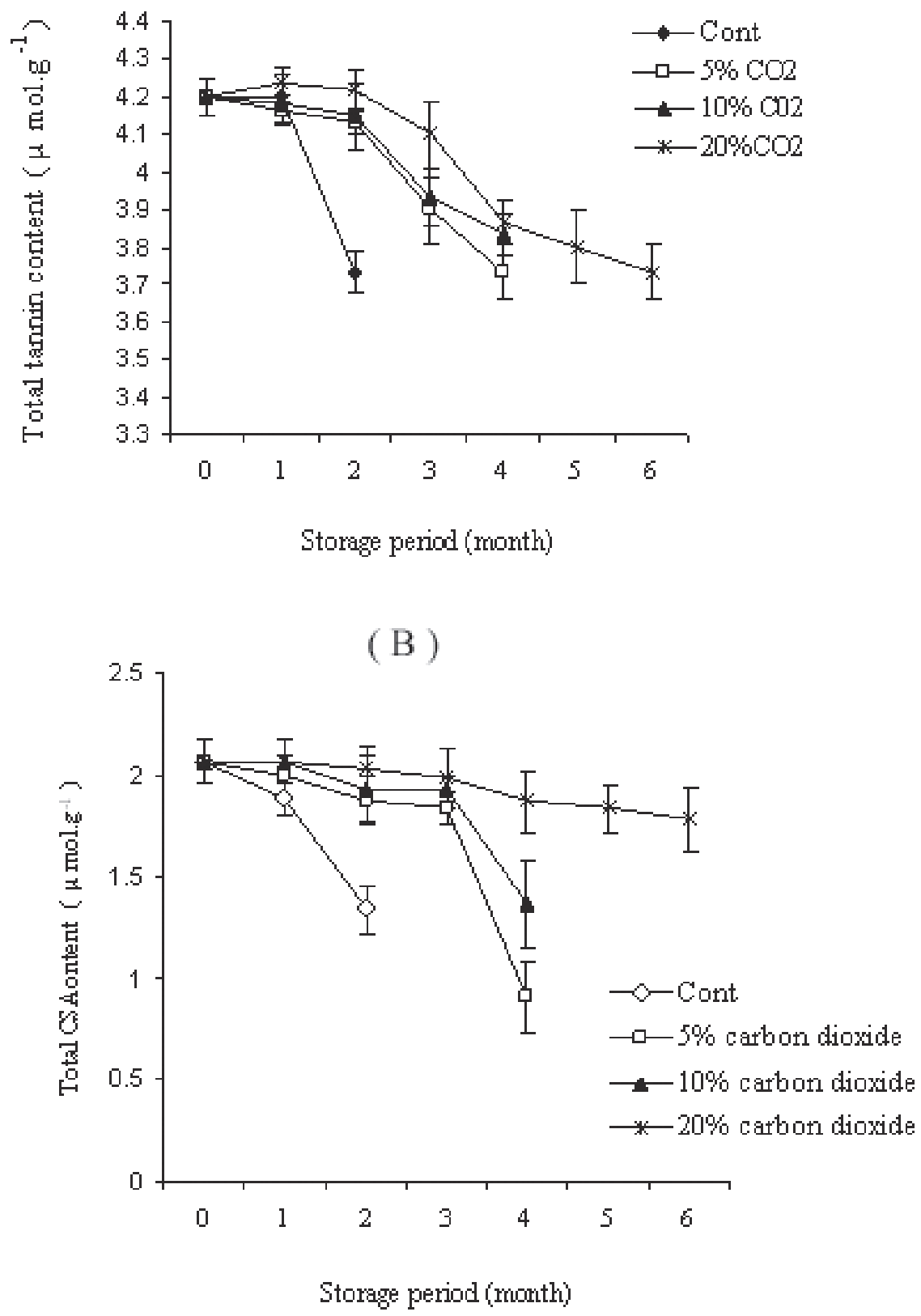

Fig. 2. Changes in (A) total tannin content $\left(\mu \mathrm{mol} \cdot \mathrm{g}^{-1}\right)$ dry weight) and (B) caffeolshikimic acid (CSA) content $\left(\mu \mathrm{mol} \cdot \mathrm{g}^{-1}\right)$ in 'Barhi' dates stored at $0{ }^{\circ} \mathrm{C}$ under different $\mathrm{CO}_{2}$ conentrations. Verticle bars show $\mathrm{SE}$ values of five replications. Three measurements were conducted for each replication.

by treatment (data not shown), perhaps because this factor was only slightly affected by ripening; the overall average SSC for mature unripe and ripe fruit was $28 \%$ and $30 \%$, respectively. At the third and fourth month of the storage period, a slight increase in SSC occurred in most treatments after 3 and 4 weeks of storage. This increase could be due to the conversion of some insoluble compounds into soluble compounds (such as the conversion of proto pectin into pectin), or as a result of greater weight loss of fruit and thus lower moisture content as shown by Thompson and Abboodi (2003).

Fruit caffeoylshikimic acid content. $\mathrm{CO}_{2}$ treatments increasingly retarded loss of SCA

The postharvest storage period possible for 'Barhi' date fruit can be markedly improved by exposure to elevated $\mathrm{CO}_{2}$ concentrations up to $20 \% \mathrm{CO}_{2}$. These conditions maintained tannin the fruit. Overall, these results suggest that a modified atmosphere system could be devel- oped for mature date fruit to retard ripening and senescence and allow shipping of fruit to distant markets with acceptable quality.

\section{Literature Cited}

Al-Redhaiman, K.N. 2002. Effect of modified atmosphere, precooling, and storage temperature on quality and respiration rate of strawberry fruits. Zagazig J. Agr. Res. 29:1493-1501.

Association of Official Agricultural Chemists (AOAC). 1975. Official methods of analysis, 12th ed. p. 564-596.

Attia, M.M., A.A. Etman, A.M. Hussein, and N. El-Naggar. 1997. Effect of wrapping with two polyethylene types on postharvest behavior and shelf life of three soft date cvs. Zagazig J. Agric. Res. 24:124-134.

Coggins, C.W. and J.C.F. Knapp. 1969. Growth, development and softening of Deglet Noor date fruits. Date growers' Inst. Report. 46:11-14.

Dubois, M., K.A. Gilles, J.K. Hamilton, P.A. Rebers, and F. Smith. 1956. Colorimetric method for determination of sugars and related substances. Anal. Chem. 28:350-356.

El-Rayes, D.A. and D.M Ahmed. 2001. Effect of modified atmosphere packaging and cold storage on storage period and quality of "Tommy Atkins" mango fruits. Assiut J. of Agr. Sci. 32:251-262.

Hassan, I.M. and M.G. El-Sheemy. 1989. Freeze thaw biochemical changes in three Egyptian date varieties. Annals Agric. Sci. Cairo. 34:205-222.

Hegazy, M.K., M.A. Fahmy, M.A. Sobaih, and M.A. Abdul-Samad. 2003. Effect of some postharvest treatments on Zagloul date fruits during storage. Proceedings of the International Conference on Date Palm. King Saud Univ., Qassim, Kingdom of Saudi Arabia: 353-362.

Kader,A.A. 1980. Prevention of ripening in fruits by use of controlled atmospheres. Food Tech. 34:51-54.

Kader,A. A. 1997. A summary of CA and MAP requirements and recommendations for fruit other than apples and pears, p. 14. In: A.A. Kader (ed.). CA 1997 Proc. vol. 3. Postharvest horticulture Ser. 17. Postharvest Outreach Prog., Univ. Calif., Davis.

Modafar, C.E, A. Tantaoui, and E.E. Boustani. 2000. Effect of caffeoyl-shikimic acid of date palm roots on activity and production of Fusarium oxysporum f.sp. albedinis cell wall-degrading enzymes . J. Phytopathol. 148:101-108.

Navarro, S., E. Donahaye, M. Rindner, A. Azrieli, U. Aksoy, L. Fergusson, and S. Hepaksoy. 1998. Storage of dried fruits under controlled atmospheres for quality preservation and control of nitidulid beetles. Acta Hort. 480:221-226.

Ramos, T., M. El-Bellaj, T.A. El-Idrissi, F. Daayf, and I. El-Hadrami. 1997. Phenolamides in the rachis of palms: components of the defence reaction of the date-palm towards Fusarium oxysporum f.sp. albedinis, the causal agent of 'Bayoud'. J. Phytopathol. 145:487-493.

Regnault, R.C., R. Hadidane, J.F. Biard, and K. Boukef. 1987. High performance liquid and thin-layer chromatographic determination of phenolic acids in palm (Phoenix dactylifera $\mathrm{L}$.) products. Food Chem. 25:61-71.

Rouhani, I. and A. Bassiri. 1976. Changes in physi$\mathrm{cal}$ and chemical characteristics of Shaahni dates during development and maturity. J. Hort. Sci. 51:489-494.

Rygg, G.L., J.R. Furr, R.W. Nixon, and W.W. Armstrong. 1953. Factors affecting the spoilage of dates at room temperature. Date Grower's Inst. 30:10-13.

Sawaya, W.M. and A.S. Mashadi. 1983. Sugars, tannins, and vitamin contents of twenty-five date cultivars grown in Saudi Arabia. Proc. Date Palm Symp. King Faisal Univ. 468-479. contents of the fruit but did not affect SSC of
Snedecor, G.W. and Cochran, W.G. 1980. Statistical methods. 7th ed. Iowa State Univ. Press, Ames.

Thompson, K.A. and A.H. Abboodi. 2003. Modified atmosphere packaging, p. 363-394. Proc. Intl. Conf. Date Palm. King Saud Univ., Qassim, Kingdom of Saudi Arabia. 